Syntax Literate: Jurnal Ilmiah Indonesia p-ISSN: 2541-0849

e-ISSN: 2548-1398

Vol. 5, No. 11, November 2020

\title{
IMPLEMENTASI KEBIJAKAN PENGAWASAN PENGELOLAAN KEUANGAN DESA PADA INSPEKTORAT KABUPATEN DEMAK
}

\section{Sutardi, Hardi Warsono dan Retno Sunu Astuti}

Universitas Diponegoro (UNDIP) Semarang Jawa Tengah, Indonesia

Email: tardi_st@yahoo.com, hardie_wsn@yahoo.com dan retnosunu@yahoo.com

\section{Abstract}

This study is intended to examine the role of the Inspectorate in supervision of village government administration, monitoring of follow-up of consultations results, inspection based on community reports, and monitoring of follow-up of guidance and supervision results. The results, among others, show the Inspectorate has carried out the function of monitoring and examining suspected complaints that are planned and supported by the availability of experienced personnel, giving the examination team the authority to independently develop the objectives and examination strategies, and simplifying the supervision procedures through the Desawaskita application. However, the Inspectorate still faces obstacles, including the implementation of monitoring of follow-up of the results of consultation, guidance and supervision that is not documented, so that it cannot be monitored, the limited number of auditor personnel compared to the number of entities being examined, and applications' weaknesses that do not yet display the required information. These problems are identified using supporting and inhibiting factors, including communication, disposition, sources, and bureaucratic structures. It was concluded, among others, that the implementation of the supervisory policy by the Inspectorate runs on the function of monitoring and examining public complaints, but it has not optimally functioned in monitoring the follow-up of the results of consultation, guidance and supervision.

Keywords: Policy Implementation; Village Financial Managements; Communication; Disposition; Bureaucratic Structure; Resources.

\footnotetext{
Abstrak

Studi ini dimaksudkan untuk meneliti peran Inspektorat dalam pengawasan penyelenggaraan pemerintah desa, pemantauan tindaklanjut hasil konsultasi, pemeriksaan berdasarkan laporan masyarakat, dan pemantauan tindaklanjut hasil pembinaan dan pengawasan. Hasilnya antara lain menunjukan bahwa Inspektorat telah menjalankan fungsi pengawasan dan pemeriksaan atas dugaan pengaduan yang terencana dan didukung ketersediaan personil yang berpengalaman, memberikan kewenangan kepada tim pemeriksa untuk secara mandiri menyusun tujuan dan strategi pemeriksaan, dan menyederhanakan prosedur pengawasan melalui aplikasi Desawaskita. Namun demikian, Inspektorat masih mengalami kendala, antara lain terkait pelaksanaan pemantauan tindaklanjut hasil konsultasi, pembinaan dan pengawasan yang tidak terdokumentasi, sehingga tidak dapat dipantau, keterbatasan jumlah personil auditor dibanding banyaknya entitas yang
} 
diperiksa, dan kelemahan aplikasi yang belum menampilkan informasi yang dibutuhkan. Permasalahan tersebut didentifikasi menggunakan faktor pendukung dan penghambat, meliputi komunikasi, kecenderungan, sumber-sumber, dan struktur birokrasi. Disimpulkan bahwa implementasi kebijakan pengawasan oleh Inspektorat berjalan pada fungsi pengawasan dan pemeriksaan atas aduan masyarakat, namun belum optimal berfungsi pada pemantauan tindaklanjut hasil konsultasi, pembinaan dan pengawasan.

Kata kunci: Implementasi Kebijakan, Pengelolaan Keuangan Desa, Komunikasi, Kecenderungan, Sumber-Sumber, Struktur Birokrasi.

\section{Pendahuluan}

Good governance adalah sebuah kerangka institusional untuk memperkuat otonomi desa, karena secara substantif desentralisasi dan otonomi desa bukan hanya masalah pembagian kewenangan antar level pemerintahan, melainkan sebagai upaya membawa negara lebih dekat dengan masyarakat (Subroto, 2009). UU Nomor 6 Tahun 2014 tentang Desa merupakan salah satu bentuk perhatian pemerintah terhadap keberadaan desa. Meskipun bukan pengaturan yang pertama, UU ini merupakan tonggak pengelolaan pemerintahan desa yang lebih professional, efisien dan efektif, terbuka serta bertanggung jawab, mengingat desa atau yang disebut dengan nama lain, telah eksis sebelum Negara Kesatuan Republik Indonesia terbentuk (Penjelasan Umum UU Nomor 6 Tahun 2014).

Dengan terbitnya UU tersebut, Desa mendapatkan kewenangan dibidang penyelenggaraan pemerintahan desa, pelaksanaan pembangunan desa, pembinaan kemasyarakatan desa dan pemberdayaan masyarakat desa berdasarkan prakarsa masyarakat, hak asal usul dan adat istiadat Desa. (Pasal 18 UU Nomor 6 Tahun 2014). Termasuk didalam kewenangan tersebut adalah pengelolaan keuangan desa yang terdiri dari semua hak dan kewajiban desa yang dapat dinilai dengan uang dan menimbulkan pendapatan, belanja pembiayaan dan pengelolaan keuangan desa, yang ditetapkan dalam Anggaran Pendapatan dan Belanja Desa (APBDesa).

Salah satu tugas pemerintah daerah dalam hal pengelolaan keuangan desa, adalah terlibat dalam kegiatan pengawasan pengelolaan keuangan desa. Peraturan Pemerintah Nomor 12 Tahun 2017 tentang Pembinaan dan Pengawasan Penyelenggaraan Pemerintah Daerah, mendefinisikan pengawasan sebagai usaha, tindakan dan kegiatan yang ditujukan untuk menjamin penyelenggaraan Pemerintah Daerah berjalan efisien dan efektif sesuai dengan ketentuan peraturan perundang-undangan (Pasal 1 ayat (2)). Pengelolaan keuangan Desa tentunya harus dilakukan dengan manajemen yang baik dan akuntabel karena dana yang masuk ke Desa bukanlah dana yang kecil, melainkan sangat besar untuk dikelola oleh sebuah Pemerintahan Desa (Fahri, 2017).

Dalam konteks pengawasan pengelolaan keuangan desa, Peraturan Menteri Dalam Negeri Nomor 20 Tahun 2018 tentang Pengelolaan Keuangan Desa, mengatur fungsi pengawasan desa yang dilakukan oleh Bupati/walikota yang dikoordinasikan oleh Aparat Pengawas Internal Pemerintah (APIP), dhi Inspektorat Kabupaten/Kota. Tugas 
pengawasan oleh Inspektorat diperkuat dengan Surat Menteri Dalam Negeri Nomor 700/1281/A.1/IJ tanggal 22 Desember 2016 tentang Pedoman Pengawasan Dana Desa, sebagai satu kesatuan dari pengelolaan keuangan desa.

Penerbitan serangkaian regulasi diberbagai tingkatan serta upaya penguatan dibidang pengawasan adalah salah satu upaya pemerintah dalam rangka meningkatkan transparansi dan akuntabilitas pengelolaan keuangan desa. Namun demikian, pada praktiknya, amat disayangkan dengan masih adanya penyimpangan-penyimpangan yang terjadi pada pengelolaan keuangan desa.

Dari media dapat kita lihat informasi kasus-kasus penyimpangan tersebut, seperti data yang dirilis Indonesian Corruption Watch (ICW), peningkatan kasus korupsi dana desa dari Tahun 2015 sampai dengan 2018, yang dimuat pada harian cnnindonesia.com tanggal 17 November 2019. Demikian juga data yang dirilis Komisi Pemberatasan Korupsi (KPK) yang merilis adanya 459 laporan soal dana desa selama Januari - Juni 2017, yang dimuat dalam new.detik.com tanggal 9 Agustus 2017.

Kasus-kasus penyimpangan pada tataran regional Provinsi Jawa Tengah, diantaranya adalah dugaan korupsi dana desa di Kabupaten Brebes yang disidik oleh Kejari Brebes, atas penyimpangan dana desa Tahun 2017, dengan total kerugian diperkirakan lebih dari Rp500 juta. Demikian juga dengan kasus penyalahgunaan keuangan desa Tahun 2019 di Desa Gemulak Kecamatan Sayung Kabupaten Demak, dengan nilai kerugian mencapai Rp599,14 juta rupiah.

Komisi Pemberantasan Korupsi (KPK) dalam berita tanggal 9 Agustus 2017, menyebutkan bahwa selama Bulan Januari-Juni Tahun 2017 terdapat 459 laporan terkait pengelolaan dana desa. Jenis penyimpangan berdasarkan laporan tersebut, yaitu tidak adanya pembangunan desa, pembangunan/pengadaan barang/jasa tidak sesuai spesifikasi/RAB, dugaan mark up oleh aparat desa, tidak adanya transparansi, masyarakat tidak dilibatkan, penyelewengan dana untuk kepentingan pribadi dan lemahnya pengawasan oleh Inspektorat (Nurhayati, 2019).

Disamping informasi-informasi yang bersumber dari media, kelemahan pengawasan yang berujung pada praktik penyimpangan pengelolaan keuangan desa, juga diperoleh berdasarkan sumber informasi dari beberapa hasil penelitian. Pramesti dalam (Hasniati, 2016) menyebutkan bahwa salah satu fenomena terkait pengelolaan dana desa adalah masih rendahnya efektivitas Inspektorat daerah dalam melakukan pengawasan terhadap pengelolaan keuangan di desa, tidak terkelolanya saluran pengaduan masyarakat dengan baik dan belum jelasnya ruang lingkup evaluasi dan pengawasan oleh Camat. Senada dengan hal tersebut, (Lituhayu, 2019) juga menyimpulkan bahwa tidak jalannya fungsi pengawasan terhadap penggunaan dana desa sangat memungkinkan kepala desa melakukan korupsi.

Potensi penyimpangan pengelolaan keuangan desa, juga telah diidentifikasi oleh lembaga auditor negara dan aparat penegak hukum. (KPK, 2015) dalam kajiannya menemukan aspek-aspek potensi korupsi keuangan desa, yang salah satunya disebabkan oleh fungsi pengawasan oleh Inspektorat Daerah yang kurang efektif, saluran pengaduan masyarakat yang tidak optimal, dan ruang lingkup evaluasi dan pengawasan 
yang belum jelas. Demikian halnya dengan kajian oleh (BPK, n.d.) menyebutkan bahwa salah satu permasalahan dalam pengelolaan keuangan desa adalah terbatasnya kapasitas Inspektorat/Bawasda untuk pemeriksaan regular dan sistematis ditingkat pedesaan.

Munculnya beberapa kasus penyimpangan pengelolaan keuangan desa, menumbuhkan semangat pada tataran Pemerintah Daerah, untuk dapat mengurangi kejadian kasus korupsi dana desa. Demi menjalankan salah satu fungsi pembinaan dan pengawasan, Pemerintah Daerah mendesain suatu regulasi, yang memungkinkan bagi organisasi perangkat daerah, dapat berperan lebih aktif dalam rangka pengawasan pengelolaan keuangan desa.

Salah satunya adalah sebagaimana dilakukan oleh Pemerintah Kabupaten Demak, melalui penerbitan Peraturan Bupati Nomor 34 Tahun 2018 tentang Pembinaan dan Pengawasan Desa di Kabupaten Demak. Melalui penerbitan perbup tersebut, Pemerintah Kabupaten Demak, menugaskan Inspektorat untuk melakukan pengawasan pengelolaan keuangan desa, dalam bentuk: 1) reviu, 2) monitoring, 3) evaluasi, 4) pemeriksaan, dan 5) bentuk pengawasan lainnya.

Namun demikian, meskipun telah dilakukan upaya-upaya kontrol yang salah satunya melalui penerbitan Perbup Nomor 34 Tahun 2018, masih ditemukan beberapa permasalahan pengelolaan keuangan desa di Kabupaten Demak. Beberapa permasalahan yang muncul diantaranya kasus penyalahgunaan keuangan desa di Desa Gemulak Kecamatan Sayung yang ditangani oleh Aparat Penegak Hukum/APH, serta kelemahan praktik dan mekanisme pengelolaan keuangan desa dalam laporan hasil pemeriksaan BPK maupun Inspektorat Kabupaten Demak.

Penelitian ini bertujuan untuk mengetahui bagaimana implementasi kegiatan pengawasan Inspektorat terhadap pengelolaan keuangan desa, sebagaimana diatur dalam Peraturan Bupati Nomor 34 Tahun 2018 tentang Pembinaan dan Pengawasan Desa di Kabupaten Demak. Penekanan pada implementasi fungsi pengawasan ini, memberikan ragam yang berbeda dengan penelitian yang telah ada sebelumnya. Jika (Hasniati, 2016) dan (Lituhayu, 2019) mengidentifikasi factor-faktor penyebab adanya penyimpangan, dalam penelitian ini akan dikaji lebih lanjut, bagaimana unsur kegiatan pengawasan (sebagai salah satu penyebab penyimpangan), bekerja di tataran organisasi perangkat daerah.

Demikian halnya dengan (Husnurrosyidah \& Suendro, 2018), yang melihat unsur yang mempengaruhi potensi penyalahgunaan Dana Desa di Kabupaten Demak, yang meliputi faktor sistem akuntansi dan kompetensi akutansi. Hal ini berbeda dengan penelitian ini dimana, faktor yang berpengaruh terhadap potensi penyalahgunaan keuangan desa, ditinjau dari implementasi kegiatan pengawasan yang dilakukan oleh organisasi perangkat daerah di Kabupaten Demak.

\section{Metode Penelitian}

Penelitian ini menggunakan pendekatan kualitatif, yang menurut Bogdan dan Biklen, S, 1992 dalam (Fathonah, Kholilatusyahidah, \& Anggraini, 2019) disebutkan sebagai salah satu prosedur penelitian yang menghasilkan data deskriptif berupa ucapan 
atau tulisan dan perilaku orang-orang yang diamati. Hasil dari pendekatan kualitatif akan diuraikan secara deskriptif, yang menurut (Nazir, 2003) diartikan sebagai suatu metode dalam meneliti status sekelompok manusia, suatu objek, suatu kondisi, suatu sistem pemikiran, ataupun suatu kelas peristiwa pada masa sekarang.

Lingkup penelitian meliputi kegiatan-kegiatan yang dilakukan Pemerintah Kabupaten Demak dalam mengimplementasikan Perbup Nomor 34 Tahun 2018 dan faktor-faktor yang menghambat serta mendorong implementasi kegiatan tersebut. Pemerolehan data primer dan sekunder dilaksanakan melalui observasi pada obyek yang ditelisi dengan eksplorasi, wawancara dan observasi di lapangan, serta pemanfataan dokumen, arsip, literature, peraturan perundangan, dokumen hasil pemeriksaan lembaga pengasa dan kajian ilmiah.

Fenomena yang diteliti meliputi kebijakan pengawasan oleh Inspektorat Kab Demak, sesuai bentuk-bentuk pengawasan sebagaimana diatur dalam Perbup Nomor 34 Tahun 2018, meliputi kegiatan 1) pengawasan penyelenggaraan pemerintah desa, 2) pemantauan tindaklanjut hasil konsultasi, 3) pemeriksaan atas dugaan penyimpangan berdasarkan laporan masyarakat, dan 4) pemantauan tindaklanjut hasil pembinaan dan pengawasan. Penelitian akan melihat faktor-fakto pendukung dan pengambat implementasi kebijakan, akan dilihat dari sisi komunikasi, sumber-sumber daya dalam OPD, kecenderungan-kecenderungan dan struktur birokrasi yang berlaku.

Teknik analisa data menggunakan tahapan pengumpulan data (data collection), penyajian data (data display), verifikasi data (data verification), dan penarikan kesimpulan (drawing conclusion), merujuk pada teknis yang dikembangkan oleh (Anggito \& Setiawan, 2018).

\section{Hasil dan Pembahasan}

\section{A. Hasil Penelitian}

\section{Pengawasan penyelenggaraan pemerintahan desa}

Pengawasan Desa adalah upaya pemerintah daerah untuk memastikan pencapaian hasil untuk menjamin pengelolaan keuangan desa berjalan sesuai rencana dan peraturan perundangan-undangan. Sesuai dengan Pasal 1 dan Pasal 7 Perbup Nomor 34 Tahun 2018, Inspektorat menjalankan fungsi pengawasan yang meliputi kegiatan; 1) pengujian atas ketaatan pada peraturan perundangundangan, 2) penilaian efisiensi dan efektivitas pengelolaan keuangan desa, 3) pelaksanaan program strategis nasional dan program unggulan Bupati, 4) berakhirnya masa jabatan Kepala Desa; dan 5) pengawasan dalam rangka tujuan tertentu. Sedangkan bentuk-bentuk pengawasan desa meliputi reviu, monitoring, evaluasi, pemeriksaan, dan bentuk pengawasan lainnya.

Kebijakan pengawasan oleh Inspektorat ditetapkan dalam Keputusan Bupati Nomor 22 Tahun 2019 tentang Penetapan Program Kerja Pengawasan Tahunan (PKPT) Berbasis Prioritas dan Risiko Inspektorat Kabupaten Demak Tahun 2019. Berdasarkan kebijakan tersebut, kegiatan pengawasan oleh 
Inspektorat selama Tahun 2019 dan 2020 meliputi kegiatan pemeriksaan rutin dan pengawasan prioritas nasional berupa reviu penyerapan dana desa.

Kegiatan pemeriksaan rutin diwujudkan dalam bentuk/jenis pengawasan regular yang dilaksanakan oleh Inspektorat. Hasil penelitian menunjukkan, selama Tahun 2019 dan Semester I 2010, seluruh hasil pengawasan reguler Inspektorat merupakan jenis pemeriksaan yang bersifat pengujian atas ketaatan terhadap peraturan perundang-undangan. Inspektorat belum mengembangkan tujuan pemeriksaan yang dikembangkan dalam PKPT, berupa pemeriksaan yang bertujuan untuk Penilaian efisiensi dan efektivitas pengelolaan keuangan desa dan Pelaksanaan program unggulan strategis nasional dan program unggulan Bupati.

Pelaksanaan pengawasan dalam rangka berakhirnya masa jabatan Kepala Desa pada periode yang diteliti, juga tidak dilakukan, mengingat pada periode tersebut. Sedangkan pengawasan dalam rangka tujuan tertentu, dilakukan khususnya terhadap permasalahan-permasalahan yang bersifat aduan dari masyarakat dan/atau adanya hasil koordinasi dengan APH.

\section{Pemantauan tindaklanjut hasil konsultasi.}

Kegiatan konsultasi adalah salah satu bentuk dari aktivitas pembinaan, yang bertujuan untuk mendapatkan petunjuk, pertimbangan dan/atau pendapat terhadap permasalahan pengelolaan keuangan desa. Konsultasi oleh Pemerintah Desa dapat dilakukan secara langsung maupun tidak langsung melalui Camat dan dikoordinasikan dengan Tim Pembina Kabupaten. Sesuai dengan Pasal 4 ayat (1) Perbup Nomor 34 Tahun 2018, hasil pelaksanaan konsultasi inilah yang selanjutnya menjadi kewajiban Inspektorat untuk memantau tindak lanjutnya oleh Pemerintah Desa.

Sesuai dengan kebijakan pengawasan yang diatur dalam Keputusan Bupati Nomor 22 Tahun 2019, kegiatan pemantauan tindak lanjut oleh Inspektorat, hanya dilakukan atas Tindak Lanjut Hasil Pemeriksaan oleh APIP dan hasil pemeriksaan BPK. Dalam PKPT Tahun 2019 maupun Tahun 2020 tidak ditemukan lebih lanjut aktivitas dan dokumentasi pemantauan terhadap tindaklanjut hasil konsultasi yang telah dilakukan oleh Pemerintah Desa, baik kepada Tim Pembina Kecamatan, Tim Pembina Kabupaten maupun OPD dilingkungan Pemerintah Kabupaten Demak.

Hasil penelitian juga menunjukkan bahwa selama Tahun 2019 dan Semester I Tahun 2020, tidak ditemukan dokumentasi atas kegiatan konsultasi tersebut. Dengan demikian, baik dalam tataran perencanaan maupun dalam tataran pelaksanaan, aktivitas pemantauan tindaklanjut pelaksanaan hasil konsultasi tersebut, belum dilakukan oleh Inspektorat Kabupaten Demak.

\section{Pemeriksaan atas dugaan penyimpangan berdasarkan laporan masyarakat.}

Salah satu kegiatan pengawasan oleh Inspektorat adalah apabila terdapat dugaan penyimpangan pengelolaan keuangan desa berdasarkan laporan/aduan dari masyarakat (Pasal 15 Perbup Nomor 34 Tahun 2018). Kegiatan ini terdiri 
dari pelaksanaan pemeriksaan dengan berkoordinasi dengan aparat penegak hukum, bentuk-bentuk koordinasi dengan aparat penegak hukum dan dokumentasi hasil koordinasi.

Koordinasi dilakukan dalam bentuk pemberian informasi, verifikasi, pengumpulan data dan pemaparan hasil pemeriksaan dan bentuk koordinasi lain berdasarkan ketentuan perundang-undangan. Hasil koordinasi tersebut dituangkan dalam bentuk berita acara koordinasi.

Dokumentasi hasil koordinasi dalam bentuk berita acara hasil koordinasi, dengan dua kondisi, yaitu, 1) proses lebih lanjut diserahkan kepada Inspektorat, jika hasil pemeriksaan aduan yang hanya bersifat administrative, dan 2) proses selanjutnya diserahkan kepada aparat penegak hukum, jika berdasarkan bukti awal ditemukan penyimpangan bersifat pidana.

Terhadap implementasi Pasal 15 ayat (1) ini, hasil penelitian menunjukkan bahwa selama Tahun 2019 dan Semester I 2020, Inspektorat telah melakukan beberapa kerjasama dengan aparat penegak hukum, terkait kasus-kasus penyimpangan yang berindikasi pidana. Koordinasi dilakukan, baik dengan Kejaksaan Negeri maupun dengan Kepolisian Resort Demak.

Namun demikian, seluruh proses koordinasi tersebut, tidak dapat dipublikasikan secara umum, mengingat sesuai dengan Pasal 16 Perbup Nomor 34 Tahun 2018, dinyatakan bahwa hasil koordinasi tersebut bersifat rahasia dan tidak boleh diberikan kepada publik, kecuali diatur lain oleh peraturan perundang-undangan.

\section{Pemantauan tindaklanjut hasil pembinaan dan pengawasan.}

Inspektorat melakukan pemantauan tindaklanjut hasil pembinaan dan pengawasan setiap 2 (dua) bulan sekali (Pasal 18 ayat (1) Perbup Nomor 34 Tahun 2018). Pemantauan dimaksud berupa pengumpulan data dan informasi pelaksanaan pembinaan dan pengawasan desa, identifikasi dan verifikasi hasilhasil pembinaan dan pengawasan, dan identifikasi rekomendasi yang dihasilkan atas aktivitas pembinaan dan pengawasan tersebut.

Hasil penelitian menunjukkan, pelaksanaan pasal ini belum dapat diimplementasikan, karena hal-hal sebagai berikut:

a. Teknis pembinaan dan pengawasan

Sebagaimana diatur dalam Perbup Nomor 34 Tahun 2018, kegiatan pembinaan dan pengawasan tidak hanya dilaksanakan oleh Inspektorat, melainkan juga oleh OPD lain, yaitu Dinpermasdes P2KB dan Kecamatan. Belum ada upaya untuk mensinkronkan kegiatan pembinaan dan pengawasan oleh masing-masing OPD. Hal ini menyebabkan Inspektorat tidak dapat memantau seluruh aktivitas pembinaan dan pengawasan pengelolaan keuangan desa.

b. Dokumentasi kegiatan pembinaan dan pengasan

Kegiatan pembinaan dan pengawasan tidak seluruhnya didokumentasikan. Bahkan dalam banyak kasus, dilakukan secara sporadik, berupa konsultasi 
melalui saluran komunikasi yang paling sederhana (telepon/wa/sms dll), bahkan secara lisan. Hal tersebut menyulitkan Inspektorat dalam memantau pelaksanan kegiatan ini, bahkan terhadap aktivitas konsultasi yang dilakukan di OPD Inspektorat itu sendiri

\section{Faktor Pendukung dan Penghambat}

\section{a. Komunikasi}

Pembahasan unsur komunikasi ini dilakukan terhadap variabel transmisi, kejelasan dan konsistensi dalam upaya Upaya mengkomunikasikan kebijakan dilakukan oleh Inspektorat salah satunya dengan menuangkan rencana kegiatan dalam PKPT, yang ditetapkan dalam Keputusan Bupati Nomor 22 Tahun 2019 tentang Penetapan Program Kerja Pengawasan Tahunan (PKPT) Berbasis Prioritas dan Risiko Inspektorat Kabupaten Demak Tahun 2019. PKPT disusun setiap tahun anggaran, sebagai dasar dalam penyusunan Dokumen Pelaksana Anggaran (DPA) SKPD dalam rangka penyediaan anggaran.

Sebagai dokumen perencanaan, PKPT telah didesain untuk memudahkan pembagian tugas yang jelas kepada masing-masing Inspektur Pembantu Wilayah (Inspektur Pembantu Wilayah) di Inspektorat. Kejelasan ini memudahkan masing-masing Irbanwil dalam mengalokasikan tenaga auditor dibawahnya untuk melaksanakan kegiatan sesuai yang telah direncanakan. Disamping juga terdapat fakta bahwa tugas-tugas Inspektorat yang bersifat rutin, menghasilkan auditor-auditor yang berpengalaman menjalankan tugas pengawasan, sesuai dengan tujuan pengawasan.

Namun demikian, dari sisi transmisi, kejelasan rencana dalam PKPT belum sampai pada tahapan pada upaya untuk memastikan bahwa PKPT telah menjawab rincian penugasan kepada Inspektorat, terutama kewajiban pemantauan hasil konsultasi dalam rangka pembinaan dan pengawasan oleh OPD di Pemkab Demak. Demikian halnya dengan Peraturan Bupati Nomor 59 Tahun 2019 tentang Susunan Organisasi, Kedudukan, Tugas dan Fungsi serta Tata Kerja Inspektorat Kabupaten Demak, penugasan personil di Inspektorat belum secara jelas mengatur fungsi pemantauan tersebut.

Faktor pendukung dalam unsur komunikasi ini adalah, pertama, kejelasan dokumen perencanaan (PKPT) dalam memuat rencana kerja, yang memudahkan Irbanwil dalam mengalokasikan sumber daya auditor. Kedua, tugas-tugas Inspektorat bersifat rutin setiap tahun, sehingga personil Inspektorat sebagai implementator berpengalamana menjalankan fungsi yang ditugaskan, terutama dalam kegiatan pengawasan pengelolaan desa dan pemeriksaan atas dugaan berdasarkan aduan masyarakat.

Faktor-faktor yang menghambat dalam unsur komunikasi adalah, pertama, informasi mengenai tugas Inspektorat dalam Perbup Nomor 34 Tahun 2018 tidak ditransmisikan secara jelas, sehingga tidak seluruh Irbanwil dan auditor menangkap pesan yang disampaikan. Hal ini dapat 
dilihat bahwa kegagalan pemantauan hasil konsultasi, bahkan terjadi pada kasus konsultasi oleh aparat pemerintah desa kepada auditor/pihak Inspektorat, karena aktivitas tersebut tidak terdokumentasikan.

Kedua, inkonsistensi pengaturan tugas pokok dan fungsi Inspektorat dalam Peraturan Bupati Nomor 59 Tahun 2019, yang tidak sepenuhnya mendukung peran pengawasan sebagaimana ditugaskan dalam Perbup Nomor 34 Tahun 2018. Hal ini berdampak pada pelaksanaan peran pemantauan hasil kegiatan konsultasi dan pemantauan serta pemutakhiran data hasil pembinaan dan pengawasan tidak dilaksanakan.

\section{b. Sumber-sumber}

Pembahasan unsur sumber-sumber dilakukan terhadap variabel ketersediaan staf, ketersediaan informasi, ketersediaan kewenangan dan ketersediaan fasilitas. bagi para implementator. Pembicaraan tentang staf berkisar pada ketesediaan secara kuantitas maupun kualitas, informasi berkisar pada kejelasana informasi mengenai tugas implementasi yang dibebankan kepada Inspektorat, wewenang berbicara tentang ketersediaan regulasi secara resmi dan fasilitas akan menguji ketersediaan anggaran.

Pada variabel staf, Inspektorat didukung total pegawai sebanyak 43 orang, namun khusus untuk fungsi pengawasan dibebankan kepada 17 pegawai, yang terdiri dari 10 orang berkualifikasi auditor dan 7 orang berkualifikasi P2UPD, serta 4 orang Irbanwil. Jumlah tersebut dirasa belum mencukupi karena tugas Inspektorat, selain pengawasan terhadap 243 desa, yang juga menjalankan fungsi pengawasan terhadap OPD di lingkungan Pemerintah Kabupaten Demak. Kondisi tersebut berdampak pada terbatasnya kemampuan Inspektorat dalam pengawasan kepada pemerintah desa Tahun 2020, yang hanya ditargetkan sebanyak 4 LHP.

Pada variabel informasi, Inspektorat Kabupaten Demak belum menyediakan informasi yang bersifat teknis untuk personil di Inspektorat untuk menjalankan tugas dan fungsi Inspektorat dalam mengimplementasikan kegiatan pemantauan hasil konsultasi dan pemantauan tindak lanjut hasil pembinaan dan pengawasan. Hal ini berdampak pada sebagian besar personil Inspektorat tidak mengetahui fungsi tersebut, meskipun sebagian besar dari personil mengetahui kegiatan pemantauan terhadap tindak lanjut hasil pemeriksaan BPK maupun APIP.

Pada variabel wewenang, Inspektorat Kabupaten Demak memberikan kewenangan penuh terhadap Auditor dan P2UPD, yang bekerja secara tim, untuk melaksanakan fungsi pengawasan penyelenggaraan pemerintah desa dan pemeriksaan dengan tujuan tertentu atas dugaan penyimpangan berdasarkan aduan dari masyarakat. Kewenangan ini diberikan kepada auditor dan P2UPD dengan control yang dilakukan secara berjenjang melalui posisi-posisi fungsional dalam tim, meliputi anggota tim, ketua tim, pengendali teknis dan penanggung jawab. 
Faktor pendukung pada variabel sumber-sumber ini, pertama, tingkat sirkulasi personil auditor dan P2UPD level anggota tim yang rendah, dengan penugasana yang relative serupa, menghasilkan personil-personil yang berpengalaman dalam melaksanakan pengawasan dan pemeriksaan terhadap aduan masyarakat. Pengalaman ini dibutuhkan untuk mensiasati jangka waktu pengawasan yang biasanya pendek (berkisar antara satu sampai dengan dua minggu dalam masa penugasan), dengan komposisi tim yang berbeda-beda untuk setiap penugasan.

Kedua, personil pengawasan (auditor dan P2UPD) mempunyai kewenangan yang cukup besar untuk menjalankan prosedur pengawasan sebagaimana ditetapkan dalam rencana program pengawasan. Tim pemeriksa menggunakan pengalaman dan pembagian tugas yang telah ditentukan secara jelas untuk melakukan pengawasan dan menuangkan dalam LHP.

Faktor penghambat dalam variabel sumber-sumber ini, pertama jumlah personil auditor dan P2UPD yang tidak mencukupi jika dibandingkan dengan jumlah entitas yang harus diperiksa. Meskipun secara pengalaman, para auditor dan P2UPD tersebut, cukup berpengalaman melakukan pengawasan, namun obyek pengawasan yang demikian luas, tidak memungkinkan Inspektorat dapat menjangkau seluruh desa, meskipun telah menggunakan pertimbangan risiko dalam menentukan desa yang akan diperiksa.

Kedua, auditor dan P2UPD fokus pada tugas pokok dan fungsi mereka dalam melakukan pengawasan, sehingga tidak memungkinkan untuk mencurahkan perhatian yang lebih besar kepada fungsi lain dari Inspektorat, yaitu peran sebagai konsultan sekaligus memantau hasil konsultasi. Fungsi pemantauan atas tindak lanjut rekomendasi hasil pembinaan dan pengawasan juga tidak dilakukann oleh auditor dan P2UPD, melainkan oleh personil dibawah Kepala Subagian Evaluasi dan Pelaporan, sebuah jabatan eselon IV dibawah Sekretaris Inspektorat. Dengan demikian terdapat dua fungsi, yaitu pengawasan dan pemantauan hasil pengawasan yang dilaksanakan oleh dua satuan kerja di organisasi Inspektorat, yaitu Irbanwil dan Sekretariat. Baik dalam regulasi tentang SOTK Inspektorat maupun dalam Perbup Nomor 34 Tahun 2018, tidak diatur lebih lanjut ketentuan teknis yang mengatur mekanisme pemantauan, yang melibatkan dua pihak ini.

\section{c. Kecenderungan- kecenderungan}

Sebagai ujung tombak implementasi kebijakan pengawasan oleh Inspektorat, auditor dan P2UPD menjadi aktor utama dalam menampilkan kecenderungan penerimaan terhadap tugas implementatif tersebut. Meskipun pada struktur organisasi Inspektorat, terhadap pegawai diluar auditor dan P2UPD, namun pada praktiknya pegawai tersebut lebih banyak berperan dalam tugas-tugas administrative, untuk mendukung tugas pokok fungsi Inspektorat. 
Personil auditor dan P2UPD Inspektorat cenderung untuk hanya menjalankan fungsi pengawasan dan pemeriksaan atas aduan masyarakat, sebagai tugas pokok fungsi mereka. Disamping bahwa tugas-tugas pemeriksaan lain yang menjadi tanggungjawabnya, seperti reviu atas LKPD, reviu RPJMD, reviu RKPD, reviu RKA OPD, evaluasi SPIP, evaluasi LKJIP, dll. Tugas-tugas tersebut dirasakan sangat memberatkan bagi beban kerja pada auditor dan P2UPD Inspektorat. Dengan demikian, kecenderrungan keengganan untuk melaksanaan tugas diluar pemeriksaan, semata hanya karena tingginya beban kerja yang sudah ada selama ini.

Faktor pendukung dari variabel kecenderungan ini adalah personil auditor yang secara umum relative terdidik, dengan rata-rata tingkat pendidikan strata-1, sehingga mempunyai kemampuan penyelesaian masalah yang lebih tinggi. Sedangkan faktor penghambat nya adalah tingginya beban kerja yang ada, sehingga tugas pemantauan dialihkan kepada personil selain auditor, yaitu personil di Sub Bagian Evaluasi dan Pelaporan, meskipun hal tersebut juga belum optimal dalam menjawab regulasi yang ada.

\section{d. Struktur Birokrasi}

Sejak Tahun 2018, Inspektorat Kabupaten Demak telah mengembangkan aplikasi system pengawasan pengelolaan keuangan desa bernama "Desawaskita" (www.desawaskita.demakkab.go.id). Aplikasi ini disusun sebagai salah satu upaya untuk mensiasati keterbatasan kemampuan Inspektorat dalam pengawasan pengelolaan keuangan desa, terutama karena keterbatasan jumlah personil. Penggunaan aplikasi system pengawasan ini merupakan penjabaran langsung sebagaimana diatur dalam Pasal 11 Perbup Nomor 34 Tahun 2018.

Sebagai aplikasi yang bertujuan menyajikan data secara riil time, Desawaskita relative mampu menyediakan fitur informasi yang cukup lengkap mulai dari perencanaan, pelaksanaan, penatausahaan, pelaporan dan pertanggungjawaban. Seluruh fitur tersebut dapat diakses oleh masingmasing desa, dan menyajikan informasi mengenai jumlah anggaran dan persentase realisasi, untuk setiap bidang pembangunan desa, mulai dari bidang pelaksanaan pembangunan, pembinaan kemasyarakatan, pemberdayaan masyarakat dan penanggulangan bencana, keadaan darurat serta mendesak.

Namun demikian, berdasarkan hasil penelitian terhadap kualitas informasi yang tersaji pada aplikasi dimaksud, per tanggal 21 Juli 2020, menunjukkan belum seluruh informasi yang seharusnya telah disajikan pihak desa, telah tersaji pada aplikasi tersebut. Pada saat diakses persentase desa yang telah melaporkan dokumen: 1) perencanaan sebanyak 13,70\%, 2) pelaksanaan sebanyak 8,44\%, 3) penatausahaan sebanyak 1,70\%, 4) pelaporan Semster I sebanyak 3,50\%, dan 5) pertanggungjawaban sebanyak $0,00 \%$. Kondisi tersebut menunjukkan masih lemahnya ketaatan pemerintah 
desa dalam memenuhi kewajiba pelaporan dokumen pertanggungjawaban melalui aplikasi Desawaskita.

Faktor pendukung variabel struktur birokrasi ini adalah, pertama, upaya penyediaan prosedur kerja dalam implementasi pengawasan pengelolaan keuangan desa, telah disederhanakan melalui penggunaan aplikasi Desawaskita. Aplikasi tersebut didesain mampu mendeteksi unsur keterlambatan penyampaian laporan melalui aplikasi tersebut, sebagai salah satu dasar dalam penentuan sampel desa yang akan diperiksa oleh Inspektorat.

Kedua, penggunaan aplikasi Desawaskita bertujuan untuk mengurangi fragmentasi, akibat kegiatan pengawasan yang terbagi pada dua OPD, yaitu Inspektorat dan Kecamatan. Sesuai dengan Pasal 11 Perbup Nomor 34 Tahun 2018, upaya mengurangi fragmentasi dilakukan dengan sinkronisasi antara rencana jadwal kegiatan pengelolaan keuangan desa oleh Kepala Desa, pelaksanaan monitoring dan evaluasi oleh Camat kepada Desa, dan verifikasi laporan pemerintah desa oleh Camat, seluruhnya melalui aplikasi Waskita.

Faktor penghambat pada variabel struktur birokrasi ini, pertama, Pemerintah Desa belum sepenuhnya mentataati ketentuan pelaporan sebagaimana diatur dalam Pasal 11 Perbup Nomor 34 Tahun 2018, yang berakibat pada saat jangka waktu yang ditentukan, belum seluruh desa melaporkan kegiataanya melalui aplikasi Desawaskita. Identifikasi beberapa sebab permasalahan tersebut, diantaranya adalah Perangkat Desa cukup disibukkan dengan system pelaporan yang sudah ada, yaitu Sistem Keuangan Desa (Siskuedes), sehingga aplikasi Desawaskita belum mendapat porsi perhatian yang cukup untuk dipenuhi. Disamping itu, kewajiban pelaporan melalui aplikasi Desawaskita belum didukung mekanisme reward and punishment terhadap pemerintah desa yang lalai melaksanakan kewajiban pelaporan tersebut.

Kedua, meskipun secara regulasi, aplikasi Desawaskita didesaian untuk mensinkronkan kegiatan antar OPD (Kecamatan dan Inspektorat), namun pada praktiknya aplikasi belum menyediakan fitur yang memungkinkan untuk menampilkan aktivitas sikronisasi tersebut. Seluruh data yang disajikan pada apalikasi tersebut, tidak dapat diketahui apakah telah dilakukan verifikasi oleh Camat.

Ketiga, selain aplikasi pengawasan belum ada aplikasi dan/atau fitur yang menyediakan sarana bagi Pemerintah Desa untuk melakukan konsultasi, baik kepada Inspektorat maupun OPD lain, berikut hasil konsultasi pembinaan dan pengawasan beserta monitoring atas tindaklanjutnya. Tidak adanya standar prosedur yang jelas, juga mengakibatkan akitivitas konsultasi, bahkan yang dilakukan Pemerintah Desa kepada Inspektorat, tidak diatur dengan ketentuan yang baku dan tidak 
didokumentasikan. Hal tersebut akan menyulitkan ketika akan dilakukan pemantauan terhadap hasil konsultasi tersebut.

\section{B. Pembahasan}

Menurut (Mulyadi, 2016), implementasi adalah upaya untuk: 1) mengorganisir, 2) mengintepretasikan dan 3) menetapkan kebijakan yang telah diseleksi. Dengan pengertian tersebut, implementasi kebijakan merupakan serangkaian kegiatan yang antara lain meliputi pengaturan sumber daya, unit dan/atau metode pelaksanaan, intrepretasi terhadap istilah dan definisi yang berlaku kedalam petunjuk-petunjuk dan penggunaan instrument-instrumen untuk melaksanakan kebijakan.

Agustino dalam (Mulyadi, 2016) mengenalkan dua pendekatan implementasi, pertama, pendekatan top down, yang serupa dengan pendekatan command dan control, dan pendekatan bottom up yang seruap dengan pendekatan the market approach. Kebijakan Perbup Nomor 34 Tahun 2018 ini merupakan kebijakan yang bersifat top down, dimana tugas implementasi merupakan intepretasi dari tugas pokok dan fungsi Inspektorat sebagaimana diatur dalam Bupati Nomor 59 Tahun 2019 tentang Perubahan atas Peraturan Bupati Nomor 38 Tahun 2016 tentang Susunan Organisasi, Kedudukan, Tugas dan Fungsi serta Tata Kerja Inspektorat Kabupaten Demak.

Analisa terhadap faktor-faktor yang mempengaruhi implementasi kebijakan pengawasan pengelolaan keuangan desa pada Pemerintah Kabupaten Demak dilakukan dengan menggunakan model implementasi kebijakan menurut George C. Edward III. George C. Edward III (Winarno, 2016) menjelaskan bahwa terdapat empat faktor yang membantu atau menghambat implementasi kebijakan, meliputi: 1) komunikasi, 2) sumber-sumber, 3) kecenderungan-kecenderungan, dan 4) struktur birokrasi. Keempat variable tersebut berpengaruh secara simultan dan berinteraksi satu sama lain untuk dalam membantu dan/atau menghambat implementasi suatu kebijakan.

Komunikasi adalah bagaimana sebuah keputusan kebijakan dan perintah diteruskan dari atas dan dilaksanakan/diikuti oleh bawahan, meliputi variable: 1) bagaimana mentransmisikan informasi, 2) kejelasan informasi, dan 3) konsistensi kandungan informasi. Sumber-sumber membahas faktor sumber daya yang diperlukan untuk mengimplementasikan kebijakan, yang meliputi: 1) ketersediaan staf, 2) informasi mengenai kebijakan itu sendiri, 3) wewenang, dan 4) fasilitas (dukungan sarana prasarana fisik).

Kecenderungan dalam konteks ini adalah menggambarkan sikap para pelaksana kebijakan dalam menyikapi suatu kebijakan, yang meliputi tinjauan atas dampak dari kecenderungan-kecenderungan tersebut dan kepentingan-kepentingan organisasi maupun pandangan-pandangan yang sekiranya mempengarui kecenderungan suatu sikap. Struktur birokrasi, merupakan desain organisasi pelaksana implementasi kebijakan, meliputi desain standar prosedur kerja dan 
fragmentasi sebagai akibat beragamnya pelaksana kebijakan yang menyebar di satuan kerja-satuan kerja.

Pemilihan model ini, karena beberapa pertimbangan, diantaranya yaitu: pertama model ini menggunakan pendekatan top-down, yang mengandalkan kejelasan perintah atasan kepada bawahan, melalui saluran komunikasi yang memadai (Resmawan, 2012) Sebagai sebuah entitas yang berada dibawah struktur Pemerintah Daerah, peran Pemerintah Desa adalah sebagai pelaksana regulasi yang dikeluarkan tingkatan pemerintah diatasnya. Dengan demikian dibutuhkan kejelasan regulasi terbitan pemerintah pusat dengan regulasi tingkatan pemerintah dibawahnya.

Kedua, di Indonesia sering disebutkan bahwa inefektivitas implementasi kebijakan disebabkan karena kurangnya koordinasi dan kerjasama antara lembagalembaga Negara dan/atau pemerintah (Ulumudin, Nugroho, \& Yusuf, 2018). Dengan demikian, melalui penggunaan model Edward III ini diharapakan mampu untuk menjawab inefektivitas atas hubungan organisasi perangkat daerah pelaksana implementasi Perbup Nomor 43 tahun 2019, khususnya bidang pengawasan yang meliputi Inspektorat dan Kecamatan.

\section{Kesimpulan}

Implementasi kebijakan pengawasan pengelolaan keuangan desa oleh Inspektorat Kabupaten Demak belum berjalan sebagaimana diatur dalam Perbup Nomor 34 Tahun 2018, terutama pada Pasal 1 dan 7 (pengawasan), Pasal 4 (pemantauan tindaklanjut hasil konsultasi), dan Pasal 18 (pemantauan hasil pembinaan dan pengawasan). Pada empat bentuk pengawasan yang diteliti menunjukkan masing-masing bentuk pengawasan mencapai tingkat implementasi yang berbeda-beda.

Inspektorat telah mengimplementasikan fungsi pengawasan penyelenggaraan pemerintahan desa, dengan menggunakan personil auditor dan P2UPD yang berpengalaman, dan dengan perencanaan dalam dokumen PKPT yang jelas. Namun demikian, hal tersebut belum dibarengi dengan pelaksanaan pengawasan yang bertujuan menilai efektivitas dan efisiensi pengelolaan keuangan desa, dan pengawasan terhadap program unggulan nasional dan/atau Bupati. Hal ini berdampak pada hasil-hasil pengawasan Inspektorat belum mampu memberikan masukan kepada OPD terkait pelaksanaan kegiatan yang ekonomis dan efisien.

Pada kegiatan pemantauan tindaklanjut hasil konsultasi, Inspektorat belum sepenuhnya menjalankan fungsi tersebut, mengingat permasalahan lemahnya dokumentasi konsultasi serta belum adanya SOP pelaksanaan konsultasi. Personil pemantauan juga selama ini fokus pada kegiatan pemantauan terhadap tindaklanjut rekomendasi hasil pemeriksaan APIP dan/atau BPK.

Pada implementasi kegiatan pemeriksaan atas dugaan penyimpangan berdasarkan laporan masyarakat, Inspektorat telah menjalankan fungsi tersebut, melalui pemeriksaan yang bekerjasama dengan aparat penegak hukum. Namun demikian, karena sesuai 
regulasi yang berlaku hasil pemeriksaan tersebut bersifat rahasia, atas pelaksanaa kegiatan tersebut tidak diinformasikan ke publik.

Pada implementasi kegiatan pemantauan tindaklanjut hasil pembinaan dan pengawasan, Inspektorat terkendala pada beberapa hal teknis, dimana peran pembinaan dan pengawasan tersebar di beberapa OPD, sehingga tidak seluruh informasi kegiatan dapat diakses oleh Inspektorat. Hal ini disebabkan karena tidak adanya prosedur kerja baku, yang mengatur mekanisme pelaporan pelaksanaan pembinaan dan pengawasan, yang menghambat upaya pendokumentasian tindaklanjut atas pelaksanaan kegiatan tersebut. 


\section{BIBLIOGRAFI}

Anggito, Albi, \& Setiawan, Johan. (2018). Metodologi penelitian kualitatif. Sukabumi: CV Jejak (Jejak Publisher).

BPK. (n.d.). Kajian Penyaluran dan Penggunaan Dana Desa Serta Alokasi Dana. In 2016. Jakarta: Direktorat Litbang Ditama Revbang.

Fahri, Lutfhi Nur. (2017). Pengaruh Pelaksanaan Kebijakan Dana Desa terhadap Manajemen Keuangan Desa dalam Meningkatkan Efektivitas Program Pembangunan Desa. Jurnal Publik: Jurnal Ilmiah Bidang Ilmu Administrasi Negara, 11(1), 75-88.

Fathonah, Nur Waliya Habibatul, Kholilatusyahidah, Nur, \& Anggraini, Juwita. (2019). Dampak Perubahan Kondisi Geografis Terhadap Kehidupan Sosial Ekonomi Masyarakat Desa Sawah Baru. PKM-P, 3(2).

Hasniati, Hasniati. (2016). Model Akuntabilitas Pengelolaan Dana Desa. JAKPP (Jurnal Analisis Kebijakan \& Pelayanan Publik), 15-30.

Husnurrosyidah, Husnurrosyidah, \& Suendro, Ginanjar. (2018). Pengaruh Sistem Akuntansi dan Kompetensi Akuntansi Terhadap Potensi Penyalahgunaan Dana Desa (Studi Kasus di Kabupaten Demak). AKTSAR: Jurnal Akuntansi Syariah, $1(1), 41-56$.

KPK, Deputi Bidang Pencegahan. (2015). Laporan Hasil Kajian Pengelolaan Keuangan Desa: Alokasi Dana Desa Dan Dana Desa. Jakarta: Deputi Bidang Pencegahan, Komisi Pemberantasan Korupsi (KPK).

Lituhayu, Dyah. (2019). Rawan Korupsi Isu Dalam Implementasi Dana Desa. GEMA PUBLICA: Jurnal Manajemen Dan Kebijakan Publik, 4(1), 17-25.

Mulyadi, Deddy. (2016). Studi Kebijakan Publik dan Pelayanan Publik: Konsep dan Aplikasi Proses Kebijakan Publik Berbasis Analisis Bukti Untuk Pelayanan Publik.

Nazir, Moh. (2003). Metode Penelitian. Jakarta: Ghalia Indonesia.

Nurhayati, Melta Indah. (2019). Peran Camat Sebagai Fasilitator Dalam Penyusunan Laporan Penyelenggaraan Pemerintahan Desa Jangkar Asam. Simbur Cahaya, 25(1), 93-113.

Resmawan, Erwin. (2012). Implementasi Kebijakan Pembangunan Infrastruktur Transportasi Bandar Udara dan Jalan di Kabupaten Malinau. Universitas Hasanuddin.

Subroto, Agus. (2009). Akuntabilitas pengelolaan dana desa (studi kasus pengelolaan alokasi dana desa di desa-desa dalam wilayah Kecamatan Tlogomulyo Kabupaten Temanggung Tahun 2008). Universitas Diponegoro. 
Implementasi Kebijakan Pengawasan Pengelolaan Keuangan Desa pada Inspektorat Kabupaten Demak

Ulumudin, Ali, Nugroho, Kandung Sapto, \& Yusuf, Maulana. (2018). Evaluasi Pengelolaan Dana Desa di Desa Puser Kecamatan Tirtayasa Kabupaten Serang Tahun 2016. Universitas Sultan Ageng Tirtayasa.

Winarno, Budi. (2016). Kebijakan Publik Era Globalisasi. Yogyakarta: CAPS. 